International Journal of Multidisciplinary Research AND ANALysis

ISSN(print): 2643-9840, ISSN(online): 2643-9875

Volume 03 Issue 12 December 2020

DOI: 10.47191/ijmra/v3-i12-16, Impact Factor: 5.522

Page No.- 365-367

\title{
Local Geoecological Indicators of Sustainable Development
}

\author{
Anvar Rasulov, PhD. ${ }^{1}$, Nusratulla Alimkulov, PhD. ${ }^{2}$ \\ ${ }^{1}$ Tashkent State Pedagogical University Tashkent, Uzbekistan \\ ${ }^{2}$ Assistant Professor, Tashkent State Pedagogical University Tashkent, Uzbekistan
}

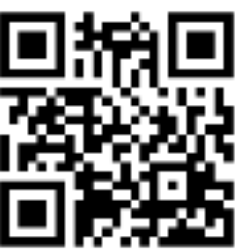

ANNOTATION: To determine the criteria for scientifically assessing the geo-ecological situation in different ecosystems in terms of sustainable development, zoning, characterization of isolated areas, determining the level of crisis, identifying factors affecting their development, mitigation, development and implementation of optimization measures it is necessary to apply.

KEYWORDS: Sustainable development, environment, geoecological situation, environmental problems, concept, biodiversity.

\section{INTRODUCTION}

Research on sustainable development shows that its conceptual idea has been developed globally and is recognized as a recommendation in countries. However, its practical application begins with the provision of "local stability" and is directed to "global stability" on a hierarchical level [2].

Therefore, it is advisable to start this research from the bottom of the "ladder" above.After all, ensuring sustainable development of Uzbekistan nationwide begins with ensuring stability in local (local, natural and socio-economic-politicaladministrative) regions.

\section{THE MAIN PART}

On local stability, including environmental indicators: theoretical analysis of regional indicators NP Tarasova, EB Kruchina [63], indicators of BR of certain state cities SN Bobylev, OV Kudryavtseva, SV Soloveva [21], rural areas E.V.Voloshenko, K.Yu.Voloshenko [3, p. 161]. Comprehensive recommendations on all aspects of sustainable development are provided by the European Environment Agency (EEA), the International Council for Local Environmental Initiatives (ICLEI), and the United Nations Center for Local Self-Government. developed by international organizations such as human settlements (UNCHS) and given as key indicators for local regions on the European continent (Table 1).

Table 1: At the local level, the environment is a key indicator of sustainable development for Europe

\begin{tabular}{|c|c|c|c|c|}
\hline № & Indicators & EEA & ICLEI & UNCHS \\
\hline 1 & Availability of drinking water & & + & + \\
\hline 2 & Emissions into the atmosphere & + & + & \\
\hline 3 & Atmospheric air quality & + & & + \\
\hline 4 & Energy use & + & + & \\
\hline 5 & Green areas & + & & \\
\hline 6 & Health & & + & + \\
\hline 7 & Child mortality rates & & & + \\
\hline 8 & The volume of investments in green areas & + & & + \\
\hline 9 & The volume of investments in water supply & + & + & + \\
\hline 10 & Organizations using environmental audit & + & & + \\
\hline 11 & Population density & + & + & \\
\hline 12 & Population growth & + & & + \\
\hline 13 & Drinking water quality & + & + & + \\
\hline
\end{tabular}


Local Geoecological Indicators of Sustainable Development

\begin{tabular}{|l|l|l|l|l|}
\hline 14 & Waste recycling & + & & + \\
\hline 15 & Water purification & + & + & + \\
\hline 16 & Water use & + & + & + \\
\hline
\end{tabular}

+ Suggested indicator.

The table is compiled by the author on the basis of data from international organizations.

On the basis of the UN Sustainable Development Program in the Republic of Uzbekistan in 2006-2008 was implemented the project "Environmental indicators for monitoring the state of the environment in Uzbekistan" (Environmental indicators for monitoring the state of the environment in Uzbekistan). Recommendation “Education for Sustainable Development - WTO" was developed by the Cabinet of Ministers of the Republic of Uzbekistan on May 27, 2013 No. 142 "Environmental Action Plan for 2013-2017" and October 20, 2018 "National Goal for Sustainable Development until 2030". and the Government's "Action Plan" and "Roadmap" for their implementation were developed and approved. However, the above-mentioned normative documents do not provide clear guidelines for sustainable development requirements and indicators at the local level. They do not indicate or systematize geoecological indicators as a separate object of research or recommendations.

Section 2 of the Roadmap for the implementation of the Action Plan (formation of a system of indicators for achieving the goals of the BR) In accordance with paragraph 5 (Development of a system of indicators to monitor the status of achieving the National Sustainable Development Goals) at the local level in the regions of the country, the tasks of conducting research systematically in accordance with the tasks set at the national level and their implementation in practice.

Our research on sustainable development and its systemic indicators has found that it is effective to use local indicators, including geo-ecological indicators, within natural geographical areas rather than within administrative units [24]. This connects and systematizes the environmental-economic-social problems in local-regional-global geosystems.

Scientists such as LS Berg, SI Abolin, VM Chetirkin, EM Murzaev, PS Makeyev, LN Babushkin and NA Kogay those who carried [1, p. 23]. In them the study of natural geographical zoning carried out by LN Babushkin and NA Kogay differs from the previous ones by its perfection. It distinguishes the following system of taxonomic units in Uzbekistan: province - province - subprovince - district - group of districts - district - landscape.

In the zoning system of LN Babushkin and NA Kogay in 1964, the territory of Uzbekistan was divided into 13 provinces: Turan province, in which the plains and foothills - mountain provinces. The system of indicators of sustainable development at the local level corresponds to the taxonomic units of natural geographical zoning at the district-group group-district-landscape level. Therefore, we considered it expedient to consider the largest natural geographical taxonomic units in the republic in the geosystems at the district level. Because the natural geographic components in a natural geographic district are reflected in a way that is close and integral to each other [2, p.246].

The small plain province of the Republic is an area in need of urgent scientific and practical research on geoecologically sustainable development. These include the Aral Sea crisis, climate change, surface and groundwater pollution and high levels of mineralization, soil salinization and degradation, and desertification (Table 2).

Separated plains and foothills - the ecological status of small mountain provinces was analyzed and compared using geoecological indicators of sustainable development (in terms of atmosphere, water, land and soil and biodiversity) for 2007-2013. According to him, the analysis of the results of the studied years on the indicators of the annual amount of solid particles in the air permissible norm took a mountain and in the mountainous province - 0.7 in the plain province -1.45 and in the country - 1.07 permissible norm. The amount of solid particles in the atmospheric air in the plains is mountainous and -2 times higher than in mountainous regions, and 1.35 times higher than in the republic. Average indicators of the use of groundwater and fresh water resources (groundwater status does not meet the standards UzDTS 950: 2000, with a salinity of more than $1.5 \mathrm{~g} / \mathrm{I}$ ) are used only in a small plain province of the republic, with a total volume of 961.1 thousand per day . m3. According to this indicator, the highest situation was detected in the Lower Zarafshan natural geographical district, which is 424.17 thousand people per day. $\mathrm{m}^{3}$.

Table 2: The plains and mountains of Uzbekistan - the mountainous provinces comparative analysis of environmental indicators

\begin{tabular}{|l|l|l|l|l|}
\hline No & $\begin{array}{l}\text { Environmental indicators and their units of } \\
\text { measurement }\end{array}$ & $\begin{array}{l}\text { Mean values determined by the analysis of indicators } \\
(2007-2013 \mathrm{y} \text {.) }\end{array}$ & The plain & Across the country \\
\cline { 3 - 6 } & $\begin{array}{l}\text { Mountains and foothills } \\
\text { REM percentage)) }\end{array}$ & 1,45 & 1,07 \\
\hline
\end{tabular}




\section{Local Geoecological Indicators of Sustainable Development}

\begin{tabular}{|l|l|l|l|l|}
\hline \multirow{2}{*}{2} & $\begin{array}{l}\text { Average value of groundwater resources (mineralization } \\
\text { rate more than } 1.5 \mathrm{~g} / \mathrm{I} \text { ), thousand } \mathrm{m}^{3} / \text { day }\end{array}$ & 0 & 961,08 & 961,08 \\
\hline \multirow{2}{*}{3} & $\begin{array}{l}\text { Average collector-drainage water consumption, mln.m } \mathrm{m}^{3} / \\
\text { year }\end{array}$ & 1159,7 & 2235,6 & 1697,7 \\
\cline { 2 - 6 } & Quality of collector-drainage waters, g/ & $1,73-2,77$ & $1,87-4,9$ & $1,8-3,83$ \\
\hline \multirow{2}{*}{4} & $\begin{array}{l}\text { Proportion of non-reclamation lands relative to total } \\
\text { irrigated lands, \% }\end{array}$ & 6,4 & 12,8 & 8,6 \\
\hline
\end{tabular}

The results of the analysis of the indicator of the total volume of collector-drainage water in the country amounted to $16093.1 \mathrm{mln} . \mathrm{m} 3$, and in the small province of the plain $-2235.6 \mathrm{mln} . \mathrm{m3}$, or $14 \%$. Analysis of solid residues in collector-drainage waters is 1.8-3.83 g / I in the country, 1.73-2.77 g / I in the foothills and mountains, 1.87-4.9 $\mathrm{g}$ in the lowlands of the plains. / I.

The share of non-reclamated lands in total irrigated lands was $8.6 \%$ in the country, $6.4 \%$ in the foothills and mountains, and $12.8 \%$ in the lowlands of the plains, and the analysis rates are much higher in the lowlands of the plains.

The results of the above analysis show that each natural geographical complex of the republic is an independent object of sustainable development.

\section{CONCLUSION}

The methodology of geo-ecological indicators of sustainable development is the selection and systematization of indicators based on the ecological situation that occurs within the natural geographical taxonomic units on a real global, regional, national or local scale. Globally, 132 of the 550 SD indicators proposed by the World Bank have been selected as environmental indicators by the United Nations Environment Program (UNEP). 118 environmental indicators for Central Asia have been proposed by the EEC and SHECOMO. At the national level, 91 indicators (68 main and 23 additional) were recommended for Uzbekistan as environmental indicators. However, the local performance of SD indicators and its geoecological features have not yet been disclosed.

\section{LIST OF USED LITERATURE}

1) Abdulqosimov A.A., Abdurahmonova Yu.X. Geoecological problems of oasis landscape protection // SamSU scientific collection.-Samarkand, 2004- P.16-23.

2) Gerasimov I.P. Environmental problems in the past, present and future geography of the World. - Moscow: Nauka, 1985.- $246 \mathrm{p}$.

3) Alekin O.A. Hydrochemistry. -L. 1952, -161 s.

4) Babushkin L.N., Kogay N.A. Physical and geographical regionalization. T .: TSU, 1964.C 247.

5) Kasimov NS et al. Geography and education for sustainable development // Bulletin of Moscow State University. Ser. 5. Geography, 2005, No. 1. -FROM. 38-48.

6) Rasulov A. History and analysis of "sustainable development" or "sustainable development" // TSPU scientific information. -T., 2018. - 4 (17). B. 20-26.

7) Kulmatov R.A., Rasulov A.B., Nigmatov A.N. Problems of the rational use of irrigated lands in the Bukhara region of Uzbekistan // Problems of the development of deserts Ashgabat, 2017.№ 1-2. S. 18-25. 